\title{
Assessing the Availability of Land and Water Resources for Production of Energy Crops in Southern Africa
}

\author{
Kelebogile B. Mfundisi \\ Land Management Department, Polytechnic of Namibia, Windhoek, Namibia \\ Email: kmfundisi@daad-alumni.de,kmfundisi@polytechnic.edu.na
}

Received July 7, 2012; revised August 7, 2012; accepted August 20, 2012

\begin{abstract}
Production of energy crops is perceived as a potential source of alternative energy for petroleum oil. However, it is crucial to ensure that there is adequate land and water available for production of energy crops before indulging into the business of producing such crops. This paper assesses the availability of land and water resources for production of energy crops in the SADC region using landuse/landcover data, hydrological and meteorological data, as well as socioeconomic data. It is found that Botswana and Mozambique have large amounts of bushland that can be used for expansion of agricultural land including production of energy crops. Zimbabwe has the highest amount of land under cultivation, which makes it difficult for the country to expand its agricultural land. However, land reform processes taking place in Zimbabwe provides a good opportunity to diversify agricultural production including reallocation of farms for production of energy crops. Mozambique has favorable rainfall for production of maize and sugarcane, whereas Zimbabwe can explore growing Jatropha on degraded land and use irrigation for cultivation of sugarcane. High frequency of crop failure in Botswana makes it difficult to grow maize or sugarcane as energy crop. The country can promote production of sweet sorghum, which is traditionally grown by small scale farmers, and explore production of Jatropha in degraded and desert land. A regional approach to address land and water requirements for production of energy crops is considered important as compared to planning for production in each country as the constraints and potential of each country can be fully recognized. More detailed country specific research is needed on the production of the specified energy crops to ensure sustainability of the production systems.
\end{abstract}

Keywords: Energy Crops; Fossil Fuels; Landuse/Landcover; Regional Approach; Water Resources

\section{Introduction}

Affordable energy services are among the essential ingredients of economic development [1]. This could help in eradication of extreme poverty and ensuring environmental sustainability in developing countries as called for by the United Nations Millennium Development Goals. Meeting these essential energy needs economically and sustainably requires a balanced energy portfolio that is suited to the economic, social, and resource conditions of individual countries and regions [2]. Currently, the major source of energy for world economies is petroleum oil, which has become expensive over the last three decades [3]. Although oil importing African countries recorded positive overall GDP growth in the past few years, there are mounting internal and external imbalances. Mounting budget deficits and inflationary pressure in oil importing African countries disproportionately affect the poor because of lower employment prospects and lack of safety nets [4]. Additionally, petroleum oil is a major source of carbondioxide, a greenhouse gas of global concern in climate change debates [5]. Therefore, an alterna- tive source of energy such as bioenergy produced from energy crops provides an affordable option for developing countries, especially those in Africa where its potential has not been fully explored. Energy crops are a source of renewable energy with reduced green house gas emissions as compared to fossil fuels. Countries in southern Africa are buying into the idea of producing energy crops due to both international pressures and the increased energy demands within them.

Bioenergy is energy produced from organic matter or biomass [3,5]. This can be in the form of bioethanol or biodiesel. Bioethanol is fuel from distilled fermented sugars and starches, and biodiesel is methyl or ethyl ester of fatty acids made from virgin or used vegetable oils [5,6]. For example, Jatropha curcus is a large fastgrowing, drought resistant perennial shrub that grows in tropical countries mainly in hedgerows. The seeds yield for Jatropha ranges from 0.5 - 12 tones/ha/year depending on soils, nutrient and rainfall conditions [7]. It can yield up to 2700 kilograms of raw oil per hectare. Projects to demonstrate the possibilities of producing bio- 
diesel from Jatropha have started in South Africa, Malawi, Lesotho, Swaziland and Zambia. Other countries in the region are also at a planning stage to embark on bioenergy production projects. However, large scale production of energy crops requires land and water resources. Setting aside land and water resources for production of energy crops is a challenge for developing countries that are also struggling to meet their food security needs and maintain ecosystems productivity. Even developing countries that have relatively high GDPs like Botswana depend on imports to meet their food security needs, and the remaining ecosystems service a lucrative wildlife based tourism industry. The two main challenges faced by these countries are: how to set aside land for production of energy crops without infringing into land available for food production and conservation of natural resources, and how to ensure that there is adequate source of water required for production of energy crops as well as that needed to sustain ecosystem productivity.

Southern Africa is comprised of countries that vary in terms of landuse/landcover, hydro-meteorological and socioeconomic aspects. This research assesses the availability of land and water resources for production of energy crops using landcover/landuse, hydro-meteorological and socioeconomic data for the SADC region (Figure 1) with particular focus on Botswana, Mozambique and Zimbabwe. The potential energy crops already grown in some countries in the SADC region are Jatropha, sugar cane, maize, and sweet sorghum. Jatropha is especially suitable for degraded land and is drought resistant. Maize can grow in all the selected countries and sugarcane grows well in Zimbabwe and Mozambique, whereas sweet sorghum is commonly grown in Botswana albeit not for energy production.

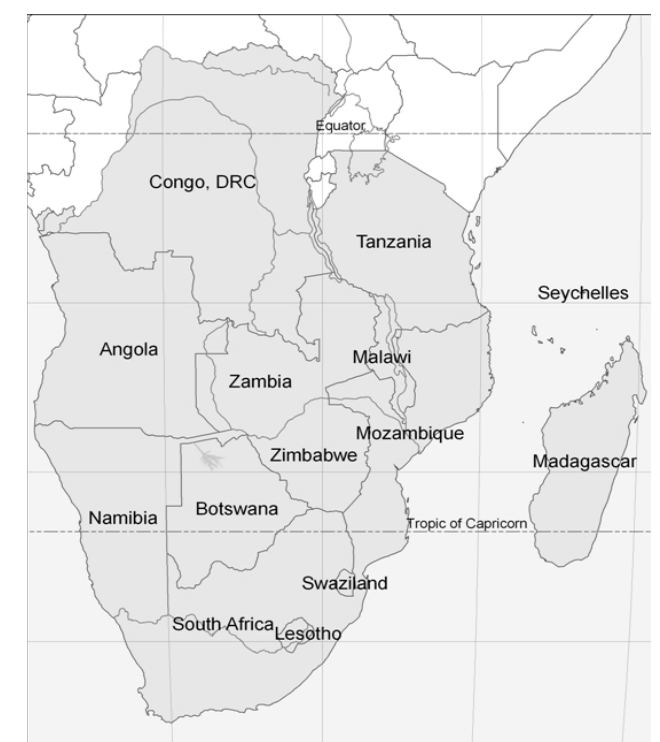

Figure 1. Map showing countries in the SADC region.

\section{Materials and Methodology}

The research was carried out using secondary data on landcover/landuse, hydrometeorology and energy consumption patterns for the SADC countries. Three countries were selected based on their energy consumption patterns and greenhouse gas emission trends. These were: Botswana, Mozambique and Zimbabwe, which had least, moderate and high carbondioxide emissions from consumption of petroleum products respectively. The landcover data for Zimbabwe and Mozambique was provided by the Southern African Development Community (SADC) office in Gaborone, whereas that for Botswana was provided by the Botswana Ministry of Agriculture. All the data on hydrometeorology was provided by SADC. And data on energy trends was downloaded from the US Energy Information Administration website [8].

\subsection{Landcover Area Estimation}

Knowledge of landcover is important for many planning and management activities concerned with the surface of the earth. This involves the use of panchromatic, medium scale aerial photos to map landcover. More recently, small scale aerial photographs and satellite images are utilized for mapping landcover of large areas. Landcover refers to the type of feature present on the surface of the earth [9]. The landcover shapefiles for this study were obtained from SADC office in Gaborone, Botswana. The data was processed using ArcView geographic information systems (GIS) tools to extract the information on different landcover types. Area covered by each landcover type was then used to estimate their percentage cover. The landcover types selected for this research were: cultivated area, bushland, bareground, forest. Bareground is regarded to be synonymous to degraded land for the purpose of this study. Land degradation includes loss of vegetation cover [10], which in this case is considered to be bareground. Soils that are of rather poor quality such as those in the Kalahari Desert of Botswana fall within another category of degraded land.

\subsection{Hydro-Meteorological Data Processing}

Hydro-meteorological data for the years 1996-2006 were obtained in spatial form and ArcView GIS was used to process it to show rainfall distribution patterns over the whole of SADC. Seasonal rainfall data was used to estimate rainfall distribution over the SADC countries at the start and end of the growing season. The growing season does not start at the same time with the rainfall season. The former is the time when crops are already accumulating biomass, whereas the later is the initial period when rainfall start and soil moisture accumulates before seeds can be sown. Since each country in SADC differs 
in terms of the timing of precipitation events, the focus of this study is on the growing season, which on average is from January to March. Simple statistical analysis such as mean values and medians were used to select places with suitable rainfall for production of energy crops using yearly data from January to March.

Water Requirement Satisfaction Index (WRSI) for the region was filtered using median value of all the countries to show places with moderate values. WRSI is a measure of the extent to which the water requirement of a particular crop has been satisfied during the growing season [11]. All the places with WRSI above the median value were selected and their spatial distribution displayed on a map. Maize was used as a reference plant because it is comparable with water requirements for sweet sorghum. It has water use efficiency (WUE) of 370 $\mathrm{kg}$ water/kg dry mater, and sweet sorghum is $310 \mathrm{~kg}$ water/kg dry mater [12]. Sugarcane has 4 times water requirement as sweet sorghum, and Jatropha curcus has the least water requirement among all the energy crops.

\section{Results and Discussion}

\subsection{Greenhouse Gas Emissions from Petroleum}

The results from analyzing energy data shows that there is increased greenhouse gas emissions from consumption of petroleum oil in the SADC Countries (Figure 2). Zimbabwe is among the countries in Southern Africa with high emission rates, Mozambique is moderate and Botswana has the least emission rates. Therefore the three countries form a good representative site for assessing the possibility of producing bioenergy crops for both reduction of greenhouse gases and carbon credits.

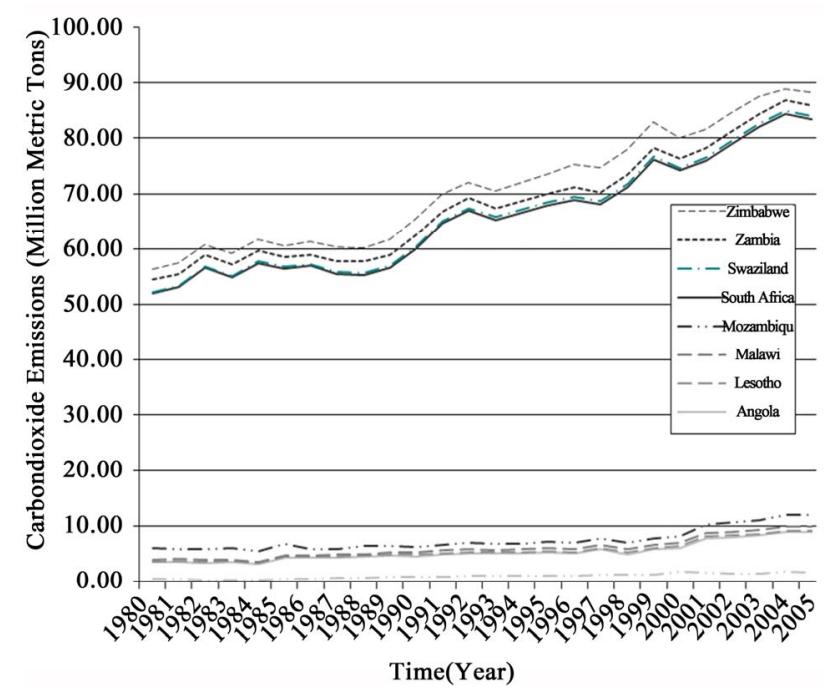

Figure 2. Carbon dioxide emissions from petroleum consumption (1980-2005).

\subsection{Landcover/Landuse}

Tables 1-3 show total area covered by the different landcover types in Botswana, Mozambique and Zimbabwe respectively.

In Zimbabwe a large area of land is used for cultivation. It is not known whether the land is still used for the intended purpose because of the land reform processes going on in the country. Generally, Biofuels require additional land [13]. Mozambique and Botswana have high percentages of land under bushland.

In addition, there is presence of degraded land in Mozambique and Zimbabwe that is suitable for growing $J$. curcus. The percentage of land used for cultivation in Mozambique is relatively low as compared to the neighboring Zimbabwe. The bushland in Mozambique provide an opportunity to expand agricultural land in the country. This expansion could include land for production of energy crops. Botswana has the least amount of area under cultivation and a large piece of land is bushland. The bushland in Botswana occurs in areas with poor sandy soils not suitable for agricultural production resulting in limitation on expansion of agricultural land. The presence of bareground in Botswana is not included here, as it is difficult to determine it because the Kalahari Desert sand covers a large portion (two thirds) of the

Table 1. Area covered by different landcover/landuse types in Botswana.

\begin{tabular}{ccc}
\hline Landcover Type & Total Area $\left(\mathrm{km}^{2}\right)$ & \% Total Land \\
\hline Cultivation & 800 & 0.1 \\
Bushland & 197,665 & 34 \\
Bareground & - & - \\
Forest & 6297 & 1.1 \\
\hline
\end{tabular}

Table 2. Area covered by different landcover/landuse types in Mozambique.

\begin{tabular}{ccc}
\hline Landcover Type & Total Area $\left(\mathrm{km}^{2}\right)$ & \% Total Land \\
\hline Cultivation & 47942.18 & 6.1 \\
Bushland & 179233.53 & 22.8 \\
Bareground & 6341.58 & 0.8 \\
Forest & 464.06 & 0.06 \\
\hline
\end{tabular}

Table 3. Area covered by different landcover/landuse types in Zimbabwe.

\begin{tabular}{ccc}
\hline Landcover Type & Total Area $\left(\mathrm{km}^{2}\right)$ & \% Total Land \\
\hline Cultivation & 107049.59 & 27.5 \\
Bushland & 48906.38 & 12.6 \\
Bareground & 1006.64 & 0.3 \\
Forest & 107.84 & 0.03 \\
\hline
\end{tabular}


country [14]. A feasibility study for production and use of biofuels in Botswana indicates that rainfall and soil conditions in the country are suitable for production of sweet sorghum and J. curcus [15]. Therefore, the bushland in Botswana is available for production of the crops. Farmers in Botswana traditionally grow sweet sorghum albeit not for production of energy. This makes it easy to promote sweet sorghum as compared to J. curcus, because little information is available to farmers about production of the later.

\subsection{Hydro-Meteorological Data}

Figures 3(a) and (b) show a trend in average rainfall distribution over the SADC countries for the beginning and end of the growing season in January and March respectively, from 2000 to 2005. Once in six years Botswana experienced average rainfall of $51-100 \mathrm{~mm}$ in the beginning of the growing season. Average rainfall above $50 \mathrm{~mm}$ in a month is adequate for crop biomass accumulation. This is particularly true for maize and sweetsorghum, which do not differ much in their water requirement and are known to perform well under such rainfall amounts. Rainfall above $100 \mathrm{~mm}$ in a month normally results in flooding conditions that are not favourable for the two crops but are particularly good for production of sugarcane. In agricultural production the spatio-temporal distribution of rainfall is important as compared to cumulative amounts. The spatio-temporal rainfall distribution can be used to determine the performance of crops over the growing season and ultimately the potential yield. Mozambique always had rainfall above $51 \mathrm{~mm}$ throughout the six years, and Zimbabwe had 2 in six years average rainfall of more than 51 $\mathrm{mm}$ for the month of January. For the end of the growing season Botswana had once again one in six years average rainfall more than $51 \mathrm{~mm}$. Zimbabwe had 2 in 6 years average rainfall over $51 \mathrm{~mm}$, and Mozambique had more than half of the time average rainfall above $51 \mathrm{~mm}$. Mozambique has enough moisture for growth of crops in the beginning of the growing season $100 \%$ of the time and more than $50 \%$ of the time the crops have enough moisture during the end of the growing season. Energy crops such as sugarcane and maize grow well under the rainfall conditions in Mozambique. The situation in Zimbabwe is also relatively better suitable for crop production as compared to Botswana as irrigation could be used to supplement rainfall. However, drought resistant crops such as Jatropha can be tried in Botswana. Also sweet sorghum survives under less rainfall conditions found in Botswana though it is currently not used as an energy crop. Its potential as an energy crop in Botswana should be explored.

The results from estimation of water requirement satis- faction index (Figure 4), using maize as a reference crop, also agree with those from the seasonal rainfall distribution. Botswana has a high percentage of crop failure over the whole country as compared to Mozambique and Zimbabwe. The northern portion of Mozambique is good for crop production as it has less amount of crop failure. This result is only applicable to the growing season of the year
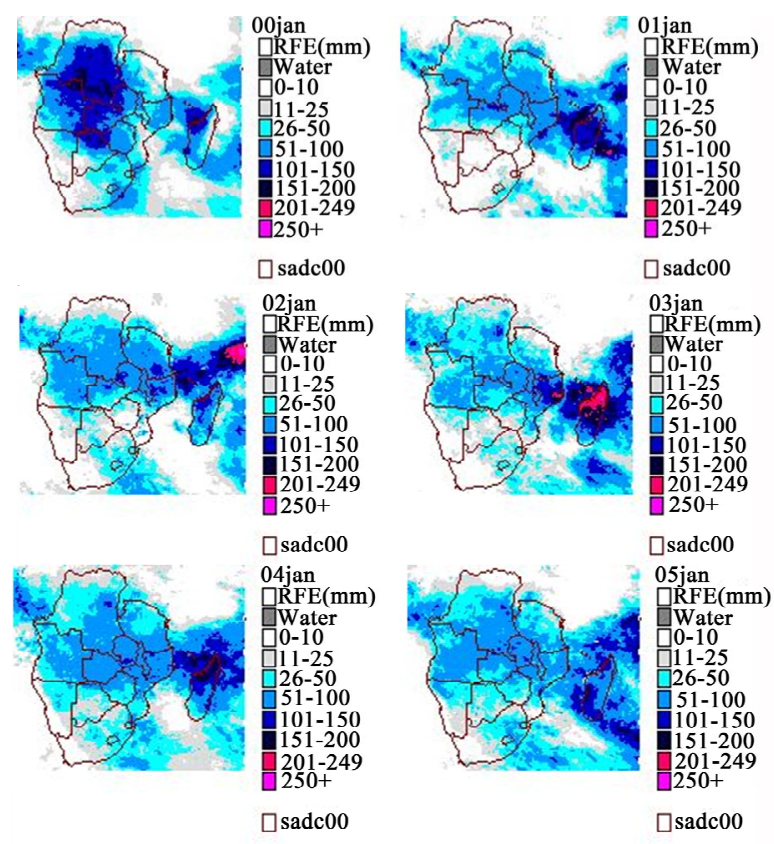

(a)
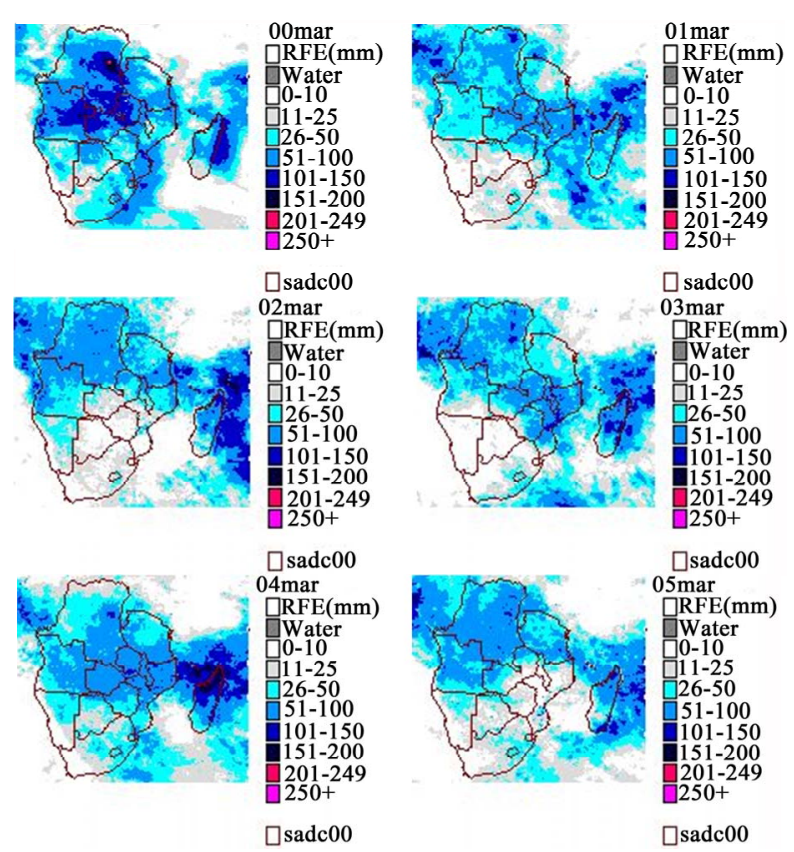

(b)

Figure 3. (a) Trends in average rainfall for the beginning of the growing season in SADC countries; (b) Trends in average rainfall for the end of the growing season in SADC countries. 

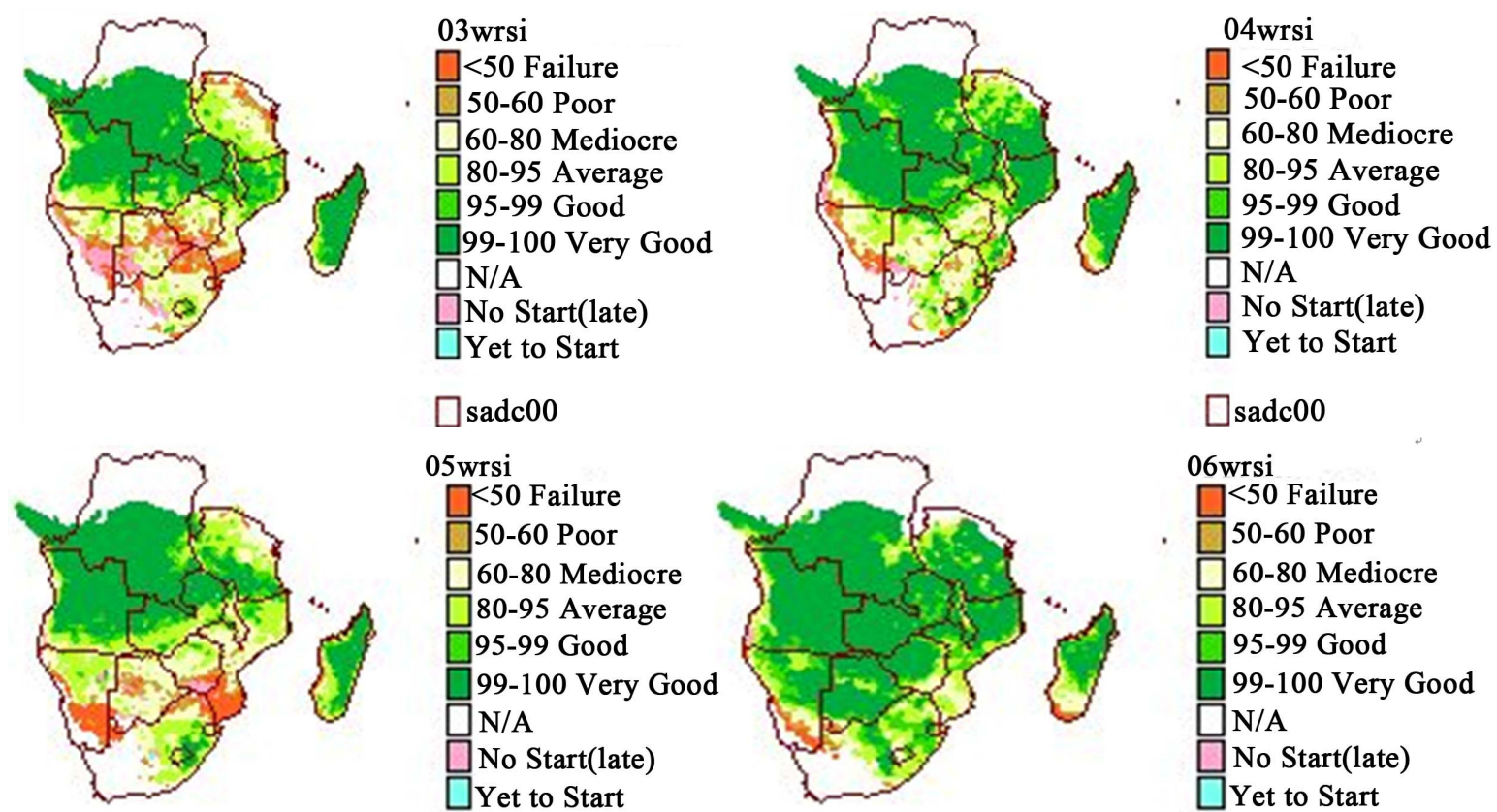

$\square \operatorname{sadc00}$
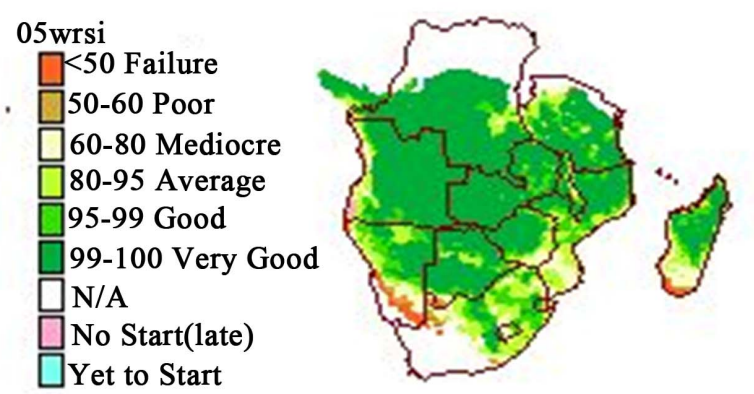

$\square \operatorname{sadc00}$

口adc00

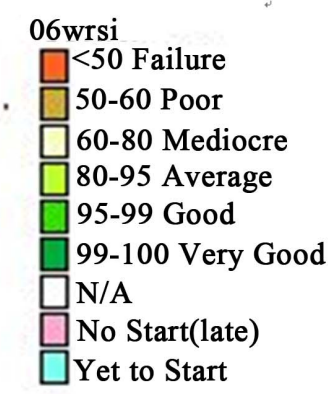

$\square \operatorname{sadc00}$

Figure 4. Maize water requirement satisfaction index (WRSI) for SADC countries.

in southern Africa, i.e. January to March. Therefore, does not apply to other periods of the year.

\section{Conclusion}

The research has revealed that Mozambique has a high amount of land available for production of energy crops. Favorable rainfall conditions in Mozambique are suitable for production of sugarcane and maize as energy crops. Zimbabwe can explore using degraded land for production of Jatropha. And Botswana has to explore growing sweet sorghum as an energy crop as well as jatropha. Farmers in Botswana are already growing sweet sorghum, which makes it easy to promote it as a potential energy crop.

\section{Acknowledgements}

The author is grateful for the data obtained from SADC Head office in Gaborone, Botswana.

\section{REFERENCES}

[1] B. Amigun, R. Sigamoney and H. von Blottnitz, "Commercialization of Biofuel Industry in Africa: A Review," Renewable and Sustainable Energy Reviews, Vol. 12, No. 3, 2006, pp. 690-711. doi:10.1016/j.rser.2006.10.019

[2] Renewable Energy Policy Network for 21 Century Report, "The Potential Role of Renewable Energy in Meeting the Millennium Development Goals”.

http://www.ren21.net
[3] UN Energy, "Sustainable Bioenergy: A Framework for Decision Makers," 2007. http://esa.un.org/un-energy/Publications.htm

[4] United Nations Economic Commission for Africa, "Economic Report on Africa 2007. Recent Economic Performance in Africa and Prospects for 2007,” 2007. http://www.uneca.org/era2007

[5] A. K. Agarwal, "Biofuels (Alcohols and Biodiesel) Applications as Fuels for Internal Combustion Engines," Progress in Energy and Combustion Science, Vol. 33, No. 3, 2007, pp. 233-271. doi:10.1016/j.pecs.2006.08.003

[6] J. C. Pasqualino, D. Montané and J. Salvadó, “Synergy Effects of Biodiesel in the Biodegradability of FossilDerived Fuels,” Biomass and Bioenergy, Vol. 30, No. 10, 2006, pp. 874-879. doi:10.1016/j.biombioe.2006.03.002

[7] G. Francis, R. Edinger and K. Becker, “A Concept for Simultaneous Wasteland Reclamation, Fuel Production, and Socio-Economic Development in Degraded Areas in India: Need, Potential and Perspectives of Jatropha Plantations," Natural Resources Forum, Vol. 29, No. 1, 2005, pp. 12-24. doi:10.1111/j.1477-8947.2005.00109.x

[8] US Energy Information Administration, "World Carbon Dioxide Emissions from the Consumption of Petroleum, 1980-2005. International Energy Annual 2005”. http://www.eia.doe.gov/emeu/international/energy.html

[9] T. M. Lillesand and R. W. Keifer, "Remote Sensing and Image Interpretation,” John Wiley \& Sons, New York, Chichester, Brisbane, Toronto, Singapore, 1987.

[10] P. L. G. Vlek, Q. B. Le and L. Tamene, "Land Decline in Land-Rich Africa,” Science Council, Consultative Group on International Agricultural Research, London, Montpel- 
lier, 2008.

[11] Southern African Development Community, "Food Security Early Warning System. Agromet-Update 5,” 2007.

[12] B. V. S. Reddy, A. A. Kumar and S. Ramesh, "Sweet Sorghum: A Water Saving Bio-Energy Crop,” International Conference on Linkages between Energy and Water Management for Agriculture in Developing Countries, International Water Management Institute, The International Crops Research Institute for the Semi-Arid Tropics Campus, Hyderabad, 29-30 January 2007, pp. 1-12.
[13] C. De Fraiture, M. Giordano and Y. Liao, "Biofuels and Implications for Agricultural Water Use: Blue Impacts of Green Energy,” Water Policy, Vol. 10, No. 1, 2008, pp. 67-81. doi:10.2166/wp.2008.054

[14] Government of Botswana, "Botswana National Atlas," Department of Surveys and Mapping, Gaborone, 2001.

[15] Government of Botswana, "Report on the Feasibility Study for the Production and Use of Biofuels in Botswana,” Department of Energy, Gaborone, 2007. 